\title{
Chemical Properties and Enzyme Activity of Soil as Affected by Tillage System and Previous Crop
}

\author{
Andrzej Woźniak \\ Department of Herbology and Plant Cultivation Techniques, University of Life Sciences in Lublin, \\ Akademicka 13, 20-950 Lublin, Poland; andrzej.wozniak@up.lublin.pl
}

Received: 14 November 2019; Accepted: 11 December 2019; Published: 12 December 2019

\begin{abstract}
The objective of this study was to evaluate the effect of tillage system and previously cultivated crop on the chemical properties and enzyme activity of soil. The first-order experimental factor was the tillage system, i.e., (1) conventional tillage (CT) and (2) reduced tillage (RT), whereas the second-order experimental factor was the previously cultivated crop, i.e., (a) pea and (b) durum wheat. Samples of soil were analyzed for the contents of organic $\mathrm{C}$, total N, available forms of $\mathrm{P}, \mathrm{K}$, and $\mathrm{Mg}$, as well as soil $\mathrm{pH}$, total sorption capacity, and activity of soil enzymes (dehydrogenases, phosphatases, ureases, and proteases). The study demonstrated that the contents of organic $\mathrm{C}$, total $\mathrm{N}$, and available forms of $\mathrm{K}$ and $\mathrm{Mg}$ as well as soil $\mathrm{pH}$ were higher in soil subjected to RT than in that subjected to CT. In plots after pea cultivation, higher values were determined for the contents of total $\mathrm{N}$ and $\mathrm{Mg}$, whereas in plots after durum wheat cultivation, the contents of organic $\mathrm{C}, \mathrm{P}$, and $\mathrm{K}$ and the soil $\mathrm{pH}$ were higher. Higher activities of dehydrogenases and phosphatases in soil were noted in soils subjected to the CT system than in those subjected to the RT system, whereas the activities of ureases and proteases were higher in soils subjected to RT. In addition, higher activities of dehydrogenases, phosphatases, and proteases were determined in the soil after pea cultivation than after durum wheat cultivation, whereas a higher activity of ureases was found in the soil after durum wheat cultivation. The $\mathrm{C} / \mathrm{N}$ ratio was more beneficial after $\mathrm{CT}$ than after $\mathrm{RT}$, as well as in the soil from plots after pea cultivation than after durum wheat cultivation.
\end{abstract}

Keywords: enzyme activity of soil; chemical properties of soil; tillage system; previous crops

\section{Introduction}

The quality and chemical composition of post-harvest residues as well as the tillage system affect soils' chemical properties and enzyme activity [1-3]. In soil cultivated according to the no-till system, the contents of organic carbon, total nitrogen, and nutrients are higher than in soil cultivated according to the conventional ploughing system [4-7]. The study conducted by Woźniak and Kawecka-Radomska [8] demonstrated that the soil subjected to a crop rotation system was characterized by higher activities of dehydrogenases, phosphatases, and ureases compared to soil subjected to monoculture. A higher enzyme activity (of dehydrogenases, phosphatases, and proteases) in soil was also reported for the zero-tillage compared to the conventional tillage. According to Roldán et al. [9], dehydrogenases occur commonly in soils rich in organic matter, hence, their activity is indicative of the intensity of the respiratory metabolism of microorganisms. Phosphatases stimulate the transformation of the organic compounds of phosphorus into inorganic phosphates [10], whereas ureases take part in the process of ammonification, namely, the release of ammonia from urea, amino acids, and purine bases [11]. Proteases are responsible for the degradation of peptide bonds in proteins to free amino acids and di-peptides, which are more available to microorganisms. According to Bandick and Dick [12] as well as Balota et al. [13], enzyme activity reflects well the properties of the soil environment and changes occurring in the soil. For this reason, it may be regarded as an indicator of soil quality and 
health [14]. As reported by Clarholm [15], the most frequently analyzed enzymes in cultivated soil are phosphatases, owing to their prompter response to agrotechnical factors.

Plant residues and tillage system also affect the content of organic carbon in soil and the $\mathrm{C} / \mathrm{N}$ ratio [16]. They determine the biological activity of a soil as well as the direction and rate of organic matter transformations ongoing in it $[16,17]$. In the study conducted by Woźniak and Kawecka-Radomska [8], the soil from a plot after pea cultivation contained significantly more available forms of phosphorus, potassium, and magnesium compared to the soil from a plot after cereals cultivation. Melero et al. [18] demonstrated a higher content of organic $\mathrm{C}$ and biomass of microorganisms in the soil cultivated after reduced tillage than in that subjected to conventional tillage. Also, in the experiment conducted by Woźniak and Gos [19], the soil cultivated according to the no-till system was characterized by higher contents of organic carbon, total nitrogen, and phosphorus than the soil cultivated according to the conventional tillage system. According to Micucci and Taboada [20], ploughing ensures a higher aeration of the soil, which contributes to the rapid mineralization of organic matter, a decrease in organic carbon content, and nutrients loss.

Based on the literature on the subject, a research hypothesis can be formulated assuming that reduced tillage and legume plants increase the content of organic $C$ and of available forms of macronutrients in soil in relation to conventional tillage. Also, enzyme activity in soil subjected to reduced tillage is greater than in soil submitted to conventional tillage and cereals cultivation.

This study was aimed at determining the effect of various tillage systems and previous crops cultivation on the chemical properties and enzyme activity of soil.

\section{Material and Methods}

A field experiment with different tillage systems was established in 1989 at the Experimental Station Uhrusk ( $51^{\circ} 18^{\prime} \mathrm{N}, 23^{\circ} 36^{\prime}$ E) of the University of Life Sciences in Lublin, south-eastern Poland. Results presented in this work were obtained in 2013-2015. The experiment was carried out in a system of randomized sub-blocks $(6 \mathrm{~m} \times 25 \mathrm{~m})$ in three replications. The first-order experimental factor was the tillage system, i.e., (1) conventional tillage (CT) and (2) reduced conventional tillage (RT), whereas the second-order factor was the previously cultivated crop, i.e., (a) pea and (b) durum wheat. In autumn, shallow ploughing (at a depth of 10-12 cm) and pre-winter ploughing $(25-30 \mathrm{~cm})$ were conducted in the CT system for pea and durum wheat cultivation, whereas only a cultivator $(10-15 \mathrm{~cm})$ was applied in the RT system. In the spring, a cultivator and a pre-sowing tillage set (cultivator, string roller, and harrow) were used in both systems before sowing pea and durum wheat. Pea of Tarchalska cultivar was sown in each study year in the first decade of April, in the amount of 100 seeds per $\mathrm{m}^{2}$ and with a row spacing of $20 \mathrm{~cm}$. Before sowing, the plots were fertilized with $20 \mathrm{~kg} \mathrm{~N} \mathrm{ha}^{-1}, 17 \mathrm{~kg} \mathrm{P} \mathrm{ha}^{-1}$, and $66 \mathrm{~kg} \mathrm{~K} \mathrm{ha}^{-1}$. Durum wheat variety Duromax was sown each year of the study between 1 April and 10 April in the amount of 500 seeds $\mathrm{m}^{-2}$. Fertilization with phosphorus $\left(34 \mathrm{~kg} \mathrm{ha}^{-1} \mathrm{P}\right)$ and potassium $\left(83 \mathrm{~kg} \mathrm{ha}^{-1} \mathrm{~K}\right)$ was applied in the spring before wheat sowing. Fertilization with nitrogen $\left(120 \mathrm{~kg} \mathrm{ha}^{-1} \mathrm{~N}\right)$ was applied at the following frequencies: (1) before sowing $\left(50 \mathrm{~kg} \mathrm{ha}^{-1}\right),(2)$ at the tillering stage (23-24 in $\mathrm{BBCH}$ (Biologische Bundesanstalt, Bundessortenamt und Chemische Industrie) scale, $\left.30 \mathrm{~kg} \mathrm{ha}^{-1}\right)$, (3) at the shooting stage (34-35 BBCH, $\left.20 \mathrm{~kg} \mathrm{ha}^{-1}\right)$, and (4) at the ear formation stage (52-53 BBCH, $\left.20 \mathrm{~kg} \mathrm{ha}^{-1}\right)$. After harvesting peas, about $1.7 \mathrm{t} \mathrm{ha}^{-1}$ of crop residues remained on the plots, whereas, after durum wheat cultivation about $3.8 \mathrm{t} \mathrm{ha}^{-1}$ of crop residues was left.

The experimental field is a flat area at the altitude of $175 \mathrm{~m}$ above sea level. The soil was found to be Rendzic Phaeozem [21], composed of sandy clay with $24.3 \%$ of silty fraction and $13.2 \%$ of silt fraction. In the years of research (on average from 2013 to 2015), in the investigated area, the annual sum of atmospheric precipitation was $580 \mathrm{~mm}$, including over $350 \mathrm{~mm}$ in the period from sowing to harvesting of pea and durum wheat (from March to August). The mean annual temperature of air was $7.7^{\circ} \mathrm{C}$, whereas in the vegetative season it reaches $13.9^{\circ} \mathrm{C}$.

Soil samples collected from experimental plots were analyzed for: (1) organic $C$ content (with the Tiurin's method); (2) total N content (with the Kjeldahl's method); (3) content of different forms of 


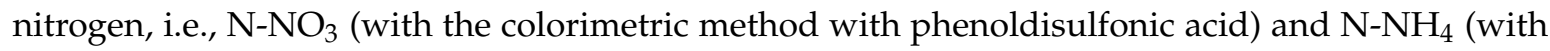
the method with Nessler's reagent); (4) C/N ratio; (5) available forms of P (with the Egner-Riehm's method), K (with the Egner-Riehm's method), and Mg (with the Schachtschabel's method); (6) soil enzymes, i.e., dehydrogenases (with the Thalmann's method), phosphatases (with the Tabataba's method), ureases (with the Zanut's method), proteases (with the Ladd and Butler's method); (7) soil

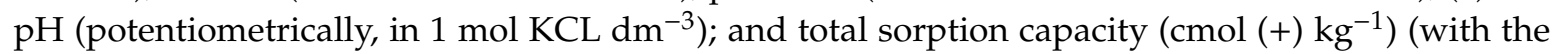
Kappen's method). For the above analyses, five initial soil samples were collected (from the $0-25 \mathrm{~cm}$ layer of soil) from each plot after the harvest of pea and durum wheat; the samples were pooled into one sample of $0.5 \mathrm{~kg}$. All determinations were made in three replicates.

The data were analyzed statistically with the method of analysis of variance (ANOVA) using the Statistica PL software (StatSoft Poland, Kraków, Poland), whereas the significance of the differences between mean values was evaluated with the Tukey's test at $p<0.05$.

\section{Results and Discussion}

The content of organic $\mathrm{C}$ in soil samples collected from RT plots was significantly higher than that of soil samples from CT plots (Table 1). Also, a higher organic C content was found in the soil sampled from plots cultivated with durum wheat than in the soil from plots where pea was previously cultivated. The content of total $\mathrm{N}$ was significantly higher in the soil from RT plots than in that from CT plots, as well as in soil from plots cultivated with pea than in soil from plots cultivated with durum wheat (Table 2). These results are consistent with those of many previous works $[3,7,19,22,23]$ which indicated that no-till cultivation facilitates the accumulation of organic $C$ and nutrients in the soil. In contrast, ploughing tillage results in greater soil aeration, which contributes to the rapid mineralization of organic matter, the decrease in organic $\mathrm{C}$ content, and the loss of nutrients [20]. Diversified tillage affects also the soil contents of saltpetre and ammonia nitrogen. Higher contents of $\mathrm{N}-\mathrm{NO}_{3}$ and $\mathrm{N}-\mathrm{NH}_{4}$ were determined in the soil from CT plots than in that from RT plots, as well as in the soil from plots submitted to pea cultivation than in the soil from plots cultivated with durum wheat (Table 3). As reported by Nannipieri et al. [11], organic matter degradation in soil is enhanced by the presence of bacteria, fungi, actinomycetes, and earthworms, as well as by moderately high temperatures and a high water content. Under such conditions, soil enzymes degrade protein compounds to ammonia which depending on the air temperature and water content of the soil, may undergo nitrification or migrate into the atmosphere [11]. The rate and direction of organic matter transformation are also determined by the $\mathrm{C} / \mathrm{N}$ ratio $[17,24-26]$. In the presence of past-harvest residues of leguminous plants, the $\mathrm{C} / \mathrm{N}$ ratio is reduced compared to its value in the presence of cereal residues [16]. A high $\mathrm{C} / \mathrm{N}$ ratio leads to the bio-sorption of nitrogen, hence reducing its availability for plants. In our study, the $C / N$ ratio was more beneficial in soil after pea cultivation than after durum wheat cultivation, as well as in soil from CT plots than in that from RT plots (Table 4). Investigations conducted by Lenart and Sławiński [25] showed no effect of direct sowing and ploughing system on the $\mathrm{C} / \mathrm{N}$ ratio in soil.

Table 1. Content of organic $C$ in soil ( $\mathrm{g} \mathrm{kg}^{-1} \mathrm{~d} . \mathrm{m}$.) (in the $0-25 \mathrm{~cm}$ layer).

\begin{tabular}{|c|c|c|c|}
\hline \multirow{2}{*}{ Previous Crop (PC) } & \multicolumn{2}{|c|}{ Tillage System (TS) } & \multirow{2}{*}{ Mean } \\
\hline & $\mathrm{CT}^{\mathrm{a}}$ & RT & \\
\hline Pea & 6.43 & 9.60 & 8.01 \\
\hline Durum wheat & 6.80 & 10.40 & 8.60 \\
\hline Mean & 6.61 & 10.00 & - \\
\hline
\end{tabular}

${ }^{a} \mathrm{CT}$ : conventional tillage, RT: reduced tillage, LSD: least significant difference; d.m: dry matter. 
Table 2. Content of total $\mathrm{N}$ in soil $\left(\mathrm{g} \mathrm{kg}^{-1} \mathrm{~d} . \mathrm{m}\right.$.) (in the $0-25 \mathrm{~cm}$ layer).

\begin{tabular}{cccc}
\hline \multirow{2}{*}{ Previous Crop (PC) } & \multicolumn{2}{c}{ Tillage System (TS) } & \multirow{2}{*}{ Mean } \\
\cline { 2 - 3 } & CT & RT & \\
\hline Pea & 0.71 & 0.93 & 0.82 \\
Durum wheat & 0.62 & 0.80 & 0.71 \\
Mean & 0.66 & 0.86 & - \\
$L S D_{0.05}$ for TS $=0.09 ;$ PC $=0.09 ;$ TS $\times$ PC $=0.15$ & \\
\hline
\end{tabular}

Table 3. Nitrogen forms in soil (in the $0-25 \mathrm{~cm}$ layer).

\begin{tabular}{|c|c|c|c|}
\hline \multirow{2}{*}{ Previous Crop (PC) } & \multicolumn{2}{|c|}{ Tillage System (TS) } & \multirow{2}{*}{ Mean } \\
\hline & CT & RT & \\
\hline \multicolumn{4}{|c|}{$\mathrm{N}-\mathrm{NO}_{3}\left(\mathrm{mg} \mathrm{kg}^{-1}\right.$ d.m. $)$} \\
\hline Pea & 33.5 & 32.1 & 32.8 \\
\hline Durum wheat & 31.6 & 27.9 & 29.8 \\
\hline Mean & 32.6 & 30.0 & - \\
\hline \multicolumn{4}{|c|}{$L S D_{0.05}$ for $\mathrm{TS}=1.2 ; \mathrm{PC}=1.2 ; \mathrm{TS} \times \mathrm{PC}=1.9$} \\
\hline \multicolumn{4}{|c|}{$\mathrm{N}-\mathrm{NH}_{4}\left(\mathrm{mg} \mathrm{kg}^{-1}\right.$ d.m. $)$} \\
\hline Pea & 2.36 & 0.97 & 1.66 \\
\hline Durum wheat & 1.68 & 1.09 & 1.39 \\
\hline Mean & 2.02 & 1.03 & - \\
\hline \multicolumn{4}{|c|}{$L S D_{0.05}$ for $\mathrm{TS}=0.11 ; \mathrm{PC}=0.11 ; \mathrm{TS} \times \mathrm{PC}=0.19$} \\
\hline
\end{tabular}

Table 4. Value of the $\mathrm{C} / \mathrm{N}$ ratio in the $0-25 \mathrm{~cm}$ layer.

\begin{tabular}{|c|c|c|c|}
\hline \multirow{2}{*}{ Previous Crop (PC) } & \multicolumn{2}{|c|}{ Tillage System (TS) } & \multirow{2}{*}{ Mean } \\
\hline & CT & RT & \\
\hline Pea & 9.1 & 10.3 & 9.7 \\
\hline Durum wheat & 10.9 & 13.0 & 12.0 \\
\hline Mean & 10.0 & 11.7 & - \\
\hline \multicolumn{4}{|c|}{$L S D_{0.05}$ for $\mathrm{TS}=1.1 ; \mathrm{PC}=1.1 ; \mathrm{TS} \times \mathrm{PC}=$ n.s. } \\
\hline
\end{tabular}

The system of tillage was observed to affect the contents of available $\mathrm{P}, \mathrm{K}$, and $\mathrm{Mg}$ in the soil (Table 5). A higher phosphorus content was determined in the soil sampled from CT plots compared to that from RT plots, whereas higher contents of $\mathrm{K}$ and $\mathrm{Mg}$ were found in the soil from RT plots than in that from CT plots. $\mathrm{K}$ and Mg easily migrate across soil, and this process is accelerated by conventional tillage and rainfall [19]. Higher contents of phosphorus and potassium were also found in the soil after the harvest of durum wheat compared to soil previously cultivated with pea, but a higher Mg content was reported in soil after pea cultivation.

The systems of tillage and crop previously cultivated influenced also the soil $\mathrm{pH}$ (Table 6). Higher $\mathrm{pH}$ values of soil were determined in RT plots than in CT plots, as well as in plots after durum wheat cultivation compared to plots cultivated with pea. As reported by Woźniak and Kawecka-Radomska [8], reduced tillage increased soil $\mathrm{pH}$ compared to conventional tillage, whereas in the study of Lenart and Sławiński [25], the tillage system had no effect upon soil pH.

The soil samples from all experimental plots were characterized by a similar total sorption capacity (Table 7). Also in other investigations [8], diversified tillage had little effect on this parameter; however, in soil sampled from plots subjected to crop rotation, the total sorption capacity was almost twice as high as that of soil sampled from plots submitted to monoculture. This is indicative of a significantly higher capability for ionic exchange in the soil from plots that underwent crop rotation with respect to soil from plots submitted to monoculture. 
Table 5. Contents of available forms of $\mathrm{P}, \mathrm{K}$, and $\mathrm{Mg}$ in soil (in the $0-25 \mathrm{~cm}$ layer).

\begin{tabular}{|c|c|c|c|}
\hline \multirow{2}{*}{ Previous Crop (PC) } & \multicolumn{2}{|c|}{ Tillage System (TS) } & \multirow{2}{*}{ Mean } \\
\hline & $\mathrm{CT}$ & RT & \\
\hline \multicolumn{4}{|c|}{$\mathrm{P}\left(\mathrm{mg} \mathrm{kg}^{-1}\right.$ d.m.) } \\
\hline Pea & 115.6 & 104.2 & 109.9 \\
\hline Durum wheat & 145.9 & 144.8 & 145.4 \\
\hline Mean & 130.8 & 124.5 & - \\
\hline \multicolumn{4}{|c|}{$L S D_{0.05}$ for $\mathrm{TS}=6.1 ; \mathrm{PC}=6.1 ; \mathrm{TS} \times \mathrm{PC}=$ n.s. } \\
\hline \multicolumn{4}{|c|}{$\mathrm{K}\left(\mathrm{mg} \mathrm{kg}^{-1}\right.$ d.m.) } \\
\hline Pea & 220.0 & 360.1 & 290.1 \\
\hline Durum wheat & 296.3 & 345.0 & 320.6 \\
\hline Mean & 258.2 & 352.6 & - \\
\hline \multicolumn{4}{|c|}{$L S D_{0.05}$ for $\mathrm{TS}=24.5 ; \mathrm{PC}=24.5 ; \mathrm{TS} \times \mathrm{PC}=39.0$} \\
\hline \multicolumn{4}{|c|}{$\operatorname{Mg}\left(\mathrm{mg} \mathrm{kg}^{-1}\right.$ d.m. $)$} \\
\hline Pea & 61.8 & 72.6 & 67.2 \\
\hline Durum wheat & 61.4 & 62.6 & 62.0 \\
\hline Mean & 61.6 & 67.6 & - \\
\hline \multicolumn{4}{|c|}{$L S D_{0.05}$ for $\mathrm{TS}=2.1 ; \mathrm{PC}=2.1 ; \mathrm{TS} \times \mathrm{PC}=3.2$} \\
\hline
\end{tabular}

Table 6. $\mathrm{pH}_{\mathrm{KCL}}$ in the soil layer at $0-25 \mathrm{~cm}$ of depth.

\begin{tabular}{cccc}
\hline \multirow{2}{*}{ Previous Crop (PC) } & \multicolumn{2}{c}{ Tillage System (TS) } & \multirow{2}{*}{ Mean } \\
\cline { 2 - 3 } & CT & RT & \\
\hline Pea & 7.28 & 7.92 & 7.60 \\
Durum wheat & 7.90 & 7.82 & 7.86 \\
Mean & 7.59 & 7.87 & - \\
$L S D_{0.05}$ for TS $=0.08 ;$ PC $=0.08 ;$ TS $\times$ PC $=0.14$ & \\
\hline
\end{tabular}

Table 7. Total sorption capacity of soil $\left(\mathrm{cmol}(+) \mathrm{kg}^{-1}\right)$.

\begin{tabular}{cccc}
\hline \multirow{2}{*}{ Previous Crop (PC) } & \multicolumn{2}{c}{ Tillage System (TS) } & \multirow{2}{*}{ Mean } \\
\cline { 2 - 3 } & CT & RT & \\
\hline Pea & 30.4 & 46.4 & 38.4 \\
Durum wheat & 43.6 & 24.7 & 34.2 \\
Mean & 37.0 & 35.6 & - \\
$L S D_{0.05}$ for TS $=$ n.s.; PC = ns; TS $\times$ PC = n.s. & \\
\hline
\end{tabular}

On the basis of the components of the analysis of variance, it can be stated that the contents of organic carbon and total nitrogen in soil were to a larger extent determined by tillage system (TS) than by previous crop (PC) (Table 8). Other features (the contents of $\mathrm{N}^{-N_{3}}, \mathrm{~N}-\mathrm{NH}_{4}, \mathrm{P}, \mathrm{K}$, and $\mathrm{Mg}, \mathrm{pH}_{\mathrm{KCL}}$, and total sorption capacity) depended on the TS and PC to a similar extent.

The enzyme activity of soil according to the tillage system was determined (Table 9). Higher activities of dehydrogenases and phosphatases were determined in the soil from CT plots than in that from RT plots. Higher activities of ureases and proteases were noted in the soil cultivated according to RT than in that that underwent CT. The enzyme activity of soil was also affected by the crop previously cultivated. The soil from the plots previously cultivated with pea was characterized by higher activities of dehydrogenases, phosphatases, and proteases, whereas that from the plots previously cultivated with durum wheat presented a higher urease activity. As reported by Roldán et al. [9], Janvier et al. [14], and Piazza et al. [27], dehydrogenases commonly occur in soils rich in organic matter and are good indicators of the respiratory metabolism of microorganisms. Phosphatases stimulate the transformation of organic compounds of phosphorus into inorganic phosphates [10], whereas ureases take part in the 
process of ammonification, i.e., the release of ammonia from urea, amino acids, and purine bases [11]. Proteases are responsible for the degradation of the peptide bonds in proteins, leading to the formation of free amino acids and di-peptides, which are more easily available to microorganisms.

Table 8. Variance analysis of soil chemical properties.

\begin{tabular}{ccccc}
\hline Specification & Value & TS & PC & TS $\times$ PC \\
\hline Organic C & $F$ & 622.29 & 411.73 & 37.54 \\
& $p$ & $* *$ & $* *$ & $* *$ \\
Total N & $F$ & 351.00 & 101.76 & 12.07 \\
& $p$ & $* *$ & $* *$ & $*$ \\
$\mathrm{~N}^{-N O} \mathrm{NO}_{3}$ & $F$ & 420.07 & 502.25 & 89.09 \\
& $p$ & $* *$ & $* *$ & $*$ \\
$\mathrm{~N}-\mathrm{NH}_{4}$ & $F$ & 500.57 & 448.00 & 94.28 \\
& $p$ & $* *$ & $* *$ & $*$ \\
$\mathrm{P}$ & $F$ & 434.03 & 396.36 & 2.91 \\
& $p$ & $* *$ & $* *$ & n.s. \\
$\mathrm{K}$ & $F$ & 186.79 & 188.14 & 224.58 \\
& $p$ & $* *$ & $* *$ & $*$ \\
$\mathrm{Mg}$ & $F$ & 14.33 & 13.20 & 8.74 \\
& $p$ & $*$ & $*$ & $*$ \\
pH & $F C L$ & 139.38 & 133.38 & 64.5 \\
Total sorption & $F$ & $* *$ & $* *$ & $*$ \\
capacity & $p$ & 2.81 & 3.20 & 4.70 \\
& & n.s. & n.s. & n.s. \\
\hline
\end{tabular}

Table 9. Enzyme activity of soil (in the $0-25 \mathrm{~cm}$ layer).

\begin{tabular}{|c|c|c|c|}
\hline \multirow{2}{*}{ Previous Crop (PC) } & \multicolumn{2}{|c|}{ Tillage System (TS) } & \multirow{2}{*}{ Mean } \\
\hline & CT & RT & \\
\hline \multicolumn{4}{|c|}{ Dehydrogenase (mg TFP kg ${ }^{-1}$ d.m. $24 \mathrm{~h}^{-1}$ ) } \\
\hline Pea & 2.325 & 2.381 & 2.353 \\
\hline Durum wheat & 1.795 & 1.307 & 1.551 \\
\hline Mean & 2.060 & 1.844 & - \\
\hline \multicolumn{4}{|c|}{$L S D_{0.05}$ for TS $=0.202 ; \mathrm{PC}=0.202 . ; \mathrm{TS} \times \mathrm{PC}=$ n.s. } \\
\hline \multicolumn{4}{|c|}{ Phosphatase (mg PNP kg ${ }^{-1}$ d.m. $\mathrm{h}^{-1}$ ) } \\
\hline Pea & 9.625 & 8.990 & 9.307 \\
\hline Durum wheat & 7.120 & 7.119 & 7.119 \\
\hline Mean & 8.372 & 8.051 & - \\
\hline \multicolumn{4}{|c|}{$L S D_{0.05}$ for TS $=0.232 ; \mathrm{PC}=0.232 ; \mathrm{TS} \times \mathrm{PC}=0.387$} \\
\hline \multicolumn{4}{|c|}{ Urease $\left(\mathrm{mg} \mathrm{N}-\mathrm{NH}_{4}{ }^{+} \mathrm{kg}^{-1}\right.$ d.m. $\left.24 \mathrm{~h}^{-1}\right)$} \\
\hline Pea & 1.873 & 3.853 & 2.863 \\
\hline Durum wheat & 2.850 & 3.630 & 3.240 \\
\hline Mean & 2.361 & 3.741 & - \\
\hline \multicolumn{4}{|c|}{$L S D_{0.05}$ for TS $=0.265 ; \mathrm{PC}=0.265 ; \mathrm{TS} \times \mathrm{PC}=0.390$} \\
\hline \multicolumn{4}{|c|}{ Protease (mg tyrosine $\mathrm{kg}^{-1} \mathrm{~d} . \mathrm{m} . \mathrm{h}^{-1}$ ) } \\
\hline Pea & 0.681 & 1.100 & 0.890 \\
\hline Durum wheat & 0.683 & 0.886 & 0.784 \\
\hline Mean & 0.682 & 0.993 & - \\
\hline \multicolumn{4}{|c|}{$L S D_{0.05}$ for TS $=0.093 ; \mathrm{PC}=0.093 ; \mathrm{TS} \times \mathrm{PC}=0.150$} \\
\hline
\end{tabular}




\section{Conclusions}

The tillage systems and previously cultivated crop were found to affect the chemical properties and enzyme activity of soil. The RT system increased the contents of organic $\mathrm{C}$, total N, and available forms of $\mathrm{K}$ and $\mathrm{Mg}$ in the soil, as well as its $\mathrm{pH}$, compared to the CT system. In plots after pea cultivation, higher contents of total $\mathrm{N}$ and $\mathrm{Mg}$ were determined, whereas in plots after durum wheat cultivation, the contents of organic $\mathrm{C}, \mathrm{P}$, and $\mathrm{K}$ and the soil $\mathrm{pH}$ were higher. The $\mathrm{CT}$ system enhanced the activities of dehydrogenases and phosphatases in the soil compared to the RT system, whereas RT increased the activities of ureases and proteases compared to CT. In addition, higher activities of dehydrogenases, phosphatases, and proteases were found in plots after pea cultivation than in those after durum wheat cultivation, whereas a higher activity of ureases was found in plots after durum wheat cultivation. The $\mathrm{C} / \mathrm{N}$ ratio was more beneficial in plots subjected to $\mathrm{CT}$ than in those that underwent RT, as well as in plots after pea cultivation than in those after durum wheat cultivation.

Funding: This research received no external funding.

Conflicts of Interest: The authors declare no conflict of interest.

\section{References}

1. Trasar-Cepeda, C.; Leiros, M.C.; Seoane, S.; Gil-Sotres, F. Limitations of soil enzymes as indicators of soil pollution. Soil Biol. Biochem. 2000, 32, 1867-1875. [CrossRef]

2. Madari, B.; Machado, P.L.O.A.; Torres, E.; de Andrade, A.G.; Valencia, L.I.O. No tillage and crop rotation effects on soil aggregation and organic carbon in a Rhodic Ferralsol from southern Brazil. Soil Tillage Res. 2005, 80, 185-200. [CrossRef]

3. Kravchenko, Y.S.; Chen, Q.; Liu, X.; Herbert, S.J.; Zhang, X. Conservation practices and management in Ukrainian mollisols. J. Agric. Sci. Technol. 2016, 18, 845-854.

4. Baker, J.M.; Ochsner, T.E.; Venterea, R.T.; Griffis, T.J. Tillage and soil carbon sequestration-what do we really know? Agric. Ecosyst. Environ. 2007, 118, 1-5. [CrossRef]

5. Cheng, K.; Zheng, J.; Nayak, D.; Smith, P.; Pan, G. Re-evaluating the biophysical and technologically attainable potential of topsoil carbon sequestration in China's cropland. Soil Use Manag. 2013, 29, 501-509. [CrossRef]

6. Zhang, H.; Lal, R.; Zhao, X.; Xue, J.; Chen, F. Opportunities and challenges of soil carbon sequestration by conservation agriculture in China. Adv. Agron. 2014, 124, 1-36.

7. Dua, Z.; Angersb, D.A.; Renc, T.; Zhanga, Q.; Lia, G. The effect of no-till on organic C storage in Chinese soils should not be overemphasized: A meta-analysis. Agric. Ecosyst. Environ. 2017, 236, 1-11. [CrossRef]

8. Woźniak, A.; Kawecka-Radomska, M. Crop management effect on chemical and biological properties of soil. Int. J. Plant Prod. 2016, 10, 391-402.

9. Roldán, A.; Salinas-Garcia, J.R.; Alguacil, M.M.; Caravaca, F. Changes in soil enzyme activity, fertility, aggregation and $\mathrm{C}$ sequestration mediated by conservation tillage practices and water regime in a maize field. Appl. Soil Ecol. 2005, 30, 11-20. [CrossRef]

10. Eivazi, F.; Tabatabai, M.A. Phosphatases in soils. Soil Biol. Biochem. 1977, 9, 167-172. [CrossRef]

11. Nannipieri, P.; Ascher, J.; Ceccherini, M.T.; Landi, L.; Pietramellara, G.; Renella, G. Microbial diversity and soil functions. Eur. J. Soil Sci. 2003, 54, 655-670. [CrossRef]

12. Bandick, A.K.; Dick, R.P. Field management effects on soil enzyme activities. Soil Biol. Biochem. 1999, 31, 1471-1479. [CrossRef]

13. Balota, E.L.; Kanashiro, M.; Filho, A.C.; Andrade, D.S.; Dick, R.P. Soil enzyme activities under long-term tillage and crop rotation systems in subtropical agroecosystems. Braz. J. Microbiol. 2004, 35, 300-306. [CrossRef]

14. Janvier, C.; Villeneuvel, F.; Alabouvette, C.; Edel-Hermenn, V.; Mateille, T.; Steinberg, C. Soil health through soil disease suppression: Which strategy from descriptors to indicators? Soil Biol. Biochem. 2007, 39, 1-23. [CrossRef]

15. Clarholm, M. Microbial biomass $\mathrm{P}$, labile $\mathrm{P}$ and acid phosphatase activity in the humus layer of a spruce forest, after repeated additions of fertilizers. Biol. Fertil. Soils 1993, 16, 287-292. [CrossRef] 
16. Liu, L.; Kong, J.; Cui, H.; Zhang, J.; Wang, F.; Cai, Z.; Huang, X. Relationships of decomposability and $\mathrm{C} / \mathrm{N}$ ratio in different types of organic matter with suppression of Fusarium oxysporum and microbial communities during reductive soil disinfestation. Biol. Control 2016, 101, 103-113. [CrossRef]

17. Lal, R. Challenges and opportunities in soil organic matter research. Eur. J. Soil Sci. 2009, 60, 158-169. [CrossRef]

18. Melero, S.; López-Garrido, R.; Murillo, M.; Moreno, F. Conservation tillage: Short- and long-term effects on soil carbon fractions and enzymatic activities under Mediterranean conditions. Soil Tillage Res. 2009, 104, 292-298. [CrossRef]

19. Woźniak, A.; Gos, M. Yield and chemical quality of spring wheat and soil properties as affected by tillage system. Plant Soil Environ. 2014, 60,141-145. [CrossRef]

20. Micucci, F.G.; Taboada, M.A. Soil physical properties and soybean (Glycine max, Merrill) root abundance in conventionally and zero-tilled soil in the humid Pampas of Argentina. Soil Tillage Res. 2006, 86, 152-162. [CrossRef]

21. IUSS Working Group WRB. World Reference Base for Soil Resources 2014, Update 2015. International Soil Classification System for Naming Soils and Creating Legends for Soil Maps; World Soil Resources Reports No. 106; FAO: Rome, Italy, 2015; p. 192.

22. West, T.O.; Post, W.M. Soil organic carbon sequestration rates by tillage and crop rotation: A global data analysis. Soil Sci. Soc. Am. J. 2002, 66, 1930-1946. [CrossRef]

23. Angers, D.A.; Eriksen-Hamel, N.S. Full-inversion tillage and organic carbon distribution in soil profiles: A meta-analysis. Soil Sci. Soc. Am. J. 2008, 72, 1370-1374. [CrossRef]

24. Jurado, M.M.; Suárez-Estrella, F.; Vargas-García, M.C.; López, M.J.; López-González, J.A.; Moreno, J. Evolution of enzymatic activities and carbon fractions throughout composting of plant waste. J. Environ. Manag. 2014, 133, 355-364. [CrossRef] [PubMed]

25. Lenart, S.; Sławiński, P. Selected soil properties and the occurrence of earthworms under the conditions of direct sowing and mouldboard ploughing. Fragm. Agron. 2010, 27, 86-93, (In Polish, Abstract In English).

26. Powlson, D.S.; Stirling, C.M.; Jat, M.L.; Gerard, B.G.; Palm, C.A.; Sanchez, P.A.; Cassman, K.G. Limited potential of no-till agriculture for climate change mitigation. Nat. Clim. Chang. 2014, 4, 678-683. [CrossRef]

27. Piazza, G.; Pellegrino, E.; Moscatelli, M.C.; Ercoli, L. Long-term conservation tillage and nitrogen fertilization effects on soil aggregate distribution, nutrient stocks and enzymatic activities in bulk soil and occluded microaggregates. Soil Tillage Res. 2020, 196, 104482. [CrossRef] 